University of Nebraska - Lincoln

DigitalCommons@University of Nebraska - Lincoln

Design and Testing of a Closed, Stirring Respirometer for Measuring Oxygen Consumption of Channel Catfish Eggs

\author{
Eugene L. Torrans \\ United States Department of Agriculture, Itorrans@ars.usda.gov
}

Follow this and additional works at: https://digitalcommons.unl.edu/usdaarsfacpub

Part of the Agricultural Science Commons

Torrans, Eugene L., "Design and Testing of a Closed, Stirring Respirometer for Measuring Oxygen Consumption of Channel Catfish Eggs" (2007). Publications from USDA-ARS / UNL Faculty. 602. https://digitalcommons.unl.edu/usdaarsfacpub/602

This Article is brought to you for free and open access by the U.S. Department of Agriculture: Agricultural Research Service, Lincoln, Nebraska at DigitalCommons@University of Nebraska - Lincoln. It has been accepted for inclusion in Publications from USDA-ARS / UNL Faculty by an authorized administrator of DigitalCommons@University of Nebraska - Lincoln. 


\title{
Design and Testing of a Closed, Stirring Respirometer for Measuring Oxygen Consumption of Channel Catfish Eggs
}

\author{
Eugene L. Torrans* \\ U.S. Department of Agriculture, Agricultural Research Service, Thad Cochran National Warmwater \\ Aquaculture Center, Catfish Genetics Research Unit, Post Office Box 38, Stoneville, Mississippi 38776, USA
}

\begin{abstract}
A closed, stirring respirometer was designed to agitate small egg mass samples of channel catfish Ictalurus punctatus while measuring oxygen consumption by the eggs. Egg mass samples ranging in size from 15 to $46 \mathrm{~g}$ were placed on a screen platform above a magnetic stir bar in the respirometer; the degree of agitation was controlled with a magnetic stir plate. Dissolved oxygen (DO) concentration and temperature were measured with a luminescent DO sensor and meter. The respirometer was used to determine routine metabolic rate and limiting oxygen concentration (the presumed hypometabolic transition zone) on egg mass samples from 10 different spawns at 0 to $5 \mathrm{~d}$ postfertilization. Routine metabolic rate increased from $4.8 \pm 1.3(0 \mathrm{~d}$ postfertilization) to $174.0 \pm 7.8 \mathrm{mg} \mathrm{O}_{2} \cdot \mathrm{kg}^{-1} \cdot \mathrm{h}^{-1}(5 \mathrm{~d}$ postfertilization). The limiting oxygen concentration increased similarly up to $87.0 \% \pm 2.7 \%$ (maximum individual value $=$ $95.9 \%$ ) air saturation by $5 \mathrm{~d}$ postfertilization. The respirometer described could not be used for sac fry, but it proved effective with clumped channel catfish eggs. Preliminary channel catfish hatchery management recommendations are to maintain DO concentrations in hatchery troughs at air saturation at least during the last day of egg development.
\end{abstract}

Approximately $2.3 \times 10^{9}$ eggs are produced annually by the U.S. channel catfish Ictalurus punctatus industry (Steeby and Wagner 2005). The industrywide hatch rate averages close to $80 \%$ but is highly variable (Broussard and Stickney 1981). Although the basic mechanics of channel catfish hatchery operations have remained relatively unchanged since the early efforts (Clapp 1929), research has addressed several factors affecting hatch and fry survival rates.

A variety of chemical treatments have been tested on channel catfish eggs for efficacy against parasites, bacteria, and fungus. Povidone iodine, formalin, and various chloride salts have undergone review by the U.S. Food and Drug Administration (FDA) and have been classified as new animal drugs of low regulatory priority (Avery and Steeby 2004). Most recently, hydrogen peroxide has been shown to effectively control fungus on eggs (Small and Wolters 2003) and

\footnotetext{
* E-mail: 1torrans@ars.usda.gov
}

Received March 31, 2006; accepted August 22, 2006 Published online April 2, 2007 has been approved by FDA through a "low regulatory priority" ruling (Avery and Steeby 2004).

The optimum water temperature for egg incubation is in the range of $25-28^{\circ} \mathrm{C}\left(77-82^{\circ} \mathrm{F}\right)$. Water temperatures outside that range can result in a reduced hatch rate, increased deformities, or both (USFWS 1984; Tucker 1984; Busch 1985; Small and Bates 2001; Avery and Steeby 2004).

Reduced fry survival is seen when the calcium hardness is less than $10 \mathrm{mg} / \mathrm{L}$ (Tucker and Steeby 1993). A calcium chloride "drip" system is used in hatcheries having water supplies with low calcium hardness. Aeration (degassing) may be necessary if the well water supply contains any hydrogen sulfide, more than $10 \mathrm{mg}$ of $\mathrm{CO}_{2} / \mathrm{L}$, or supersaturated gases (Steeby and Avery 2005). Un-ionized ammonia, dissolved ferrous iron, and high amounts of suspended solids, all of which can affect hatch rates or survival rates, can be corrected with aeration or filtration (Avery and Steeby 2004).

Surprisingly, little research has been conducted on the dissolved oxygen (DO) requirements of channel catfish eggs (Carlson et al. 1974), and practical management recommendations vary widely. Some sources (USFWS 1984) state that "well-aerated" water should be provided in the hatchery; others recommend "oxygenated" water (Lee 1991), or a minimum DO concentration of 4 (Avery and Steeby 2004), 5 (Tucker 1984), or $6 \mathrm{mg} / \mathrm{L}$ (Jensen et al. 1987; Tucker and Robinson 1990).

Empirically determined oxygen requirements of developing channel catfish eggs would be useful in establishing more valid recommendations for oxygen management in commercial hatcheries, but measuring oxygen consumption of channel catfish eggs is problematic. Spawned eggs are demersal and adhesive (Saksena et al. 1961), held together with a glycoprotein matrix that inhibits water flow to individual eggs (Ringle et al. 1992). In nature, water is circulated through the spawn by the male channel catfish, which agitates the spawn throughout the incubation period (Clemens and Sneed 1957). This spawn agitation is simulated in hatchery troughs with paddles rotating at a rate of 30 rotations per minute (rpm) (Clapp 1929; Steeby et al. 2004). 


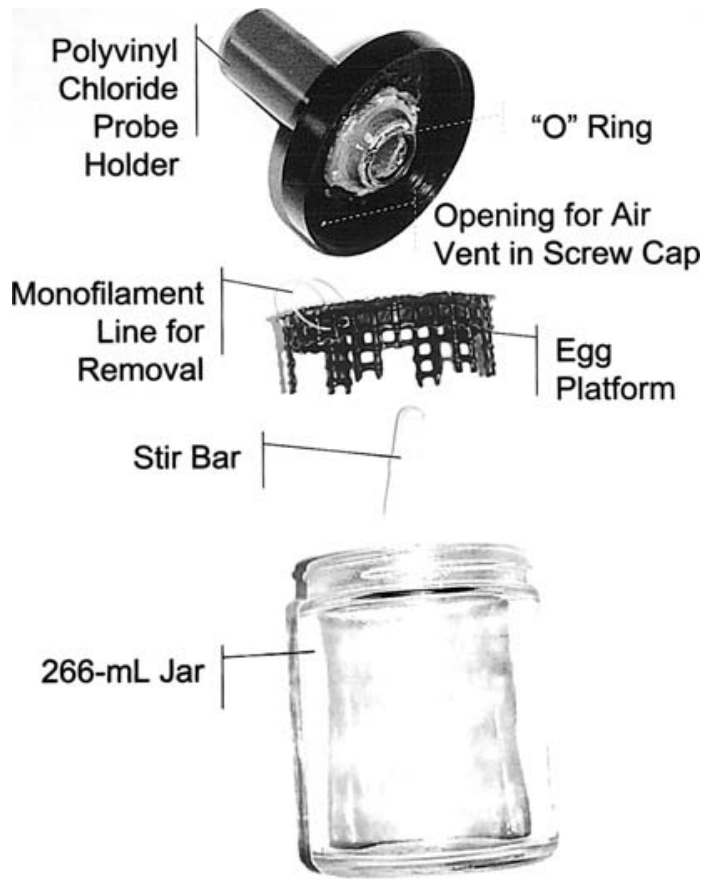

FIGURE 1.-Exploded view of a closed, stirring respirometer used to determine the oxygen consumption of channel catfish eggs. See text for details.

Here, I describe a closed, stirring respirometer developed to determine metabolic rate and oxygen requirements of clumped channel catfish eggs. Preliminary data on channel catfish eggs ranging in age from 0 to $5 \mathrm{~d}$ postfertilization are presented.

\section{Methods}

Czihak et al. (1979) described a closed respirometer within which the water was circulated with a spin bar rotated by a magnetic stirrer. This concept was used to develop a closed, stirring respirometer from readily available materials that was suitable for agitating small pieces of channel catfish spawns while measuring oxygen consumption.

The respirometer (Figure 1) was made with a 266$\mathrm{mL}$, wide-mouth glass jar (Fisher Qorpak; Fisher Scientific, Pittsburgh, Pennsylvania). A 2.54-cm-diameter hole was drilled and tapped through the center of the cap, through which a $7.1-\mathrm{cm}$ long, 1.90-cm internal diameter, schedule- 80 threaded polyvinyl chloride pipe was inserted. The pipe was secured with two aluminum conduit washers (one inside and one outside the lid). The junction was sealed, and the washers were covered with clear aquarium silicone caulk. A number-12 O-ring was glued to the inside end of the pipe with cyanoacrylate adhesive. The O-ring provided a seal around the oxygen probe, which was inserted through the pipe. The pipe also served to contain overflow created by insertion of the probe into the chamber.

A $0.24-\mathrm{cm}$-diameter hole was drilled through the top edge of the lid. A 2.54-cm length of capillary tube was inserted in the hole and glued flush with the inside surface by use of cyanoacrylate adhesive. This tube was used to bleed off any air trapped in the jar.

A short platform was made to suspend the egg sample above a $3.5-\mathrm{cm}$ magnetic stir bar that was used to agitate the egg sample and circulate water within the chamber. A $2.3-\mathrm{cm}$ tall, $6.6-\mathrm{cm}$ outer diameter, rigid tubular polypropylene mesh (Internet, Inc., Anoka, Minnesota) formed a cylindrical support for the platform. A circular piece of plastic window screen, slightly larger in diameter than the inside of the jar, was attached to the cylinder with epoxy adhesive. When placed in the jar, the edges of the screen curved up slightly, conforming to the inside surface of the jar. A piece of monofilament fishing line was attached to the platform to assist in removal.

A Hach model HQ10 luminescent DO meter (Hach Company, Loveland, Colorado) was used to measure temperature and DO concentration and saturation in the respirometer. When the sensor was inserted through the pipe (an enlargement near the middle of the sensor formed an effective stop against the top of the pipe), it extended through the O-ring and into the chamber approximately $2.2 \mathrm{~cm}$, exposing the probe's temperature sensor to the water. With the stir bar and platform in place and the sensor inserted, the water volume of the chamber was $257 \mathrm{~mL}$. The egg sample volume was subtracted from this to obtain net water volume when calculating oxygen consumption rate. "Blanks" (tests in which no eggs were used) were run periodically and showed no measurable decrease in DO during the sample times used.

Ten channel catfish spawns were collected in the morning from ponds at the Catfish Genetics Research Unit (U.S. Department of Agriculture [USDA], Agricultural Research Service [ARS]), Stoneville, Mississippi. The spawns were placed in individual plastic buckets containing a 1:150 solution of $10 \%$ povidoneiodine complex (polyvinylpyrrolidone iodine; Western Chemical, Inc., Ferndale, Washington) for 30-60 min while being transported to the hatchery. The spawns were placed in standard hatchery baskets and incubated in separate aerated $185-\mathrm{L}$ square fiberglass tanks. Water temperature averaged $\left( \pm\right.$ SE) $26.6 \pm 0.02^{\circ} \mathrm{C}$ during incubation. Eggs were treated for fungus once daily for the first $3 \mathrm{~d}$ with $30 \mathrm{~mL}$ of $35 \%$ hydrogen peroxide per tank (Small and Wolters 2003).

Egg samples (15-46 g; mean egg weight $=0.027 \mathrm{~g}$; 577-1,477 eggs per sample tested) were taken from 
spawns, drained of water, weighed and placed in the chamber. The chamber was filled with air-saturated water at incubation temperature, and the lid was attached. Air was bled off through the capillary tube, and the probe was inserted. The chamber was submerged in a water bath on a magnetic stir plate covered with a waterproof plastic shield (Figure 2). Hatchery water was circulated through the bath to maintain a test temperature $26.7 \pm 0.03^{\circ} \mathrm{C}$. The spin bar was rotated at a speed (approximately $300 \mathrm{rpm}$ ) that agitated the spawn sample in a way similar to that seen in commercial hatcheries.

The DO concentration $(\mathrm{mg} / \mathrm{L})$ and temperature in the respirometer were recorded. During the first day or two of incubation, when oxygen consumption (metabolism) was low, larger egg samples were used, and measurements were made at intervals as long as $5 \mathrm{~min}$. As the eggs developed and metabolism increased, smaller egg samples were used and measurements were made at 1min intervals. An attempt was made to complete the testing of each egg sample in 30-90 min while obtaining at least 15 data points.

Typically, over a range of (higher) DO concentrations, the oxygen consumption rate was linear (Figure 3 ), indicating that metabolism was independent of DO concentration. The slope of this portion of the line was used to calculate routine metabolic rate (Cech 1990). If spawn samples were left in the respirometer long enough, the DO concentration (\% air saturation) decreased to the apparent hypometabolic transition zone. Below this concentration, metabolism was presumably oxygen-limited and decreased (Figure 3). For convenience, I deemed this point the limiting oxygen concentration because metabolism was oxygen limited at lower concentrations. Although routine metabolism was determined on spawns of all ages, the limiting oxygen concentration was not determined on any 0-d postfertilization spawns and on only one spawn at $1 \mathrm{~d}$ postfertilization. The metabolism of younger spawns was so low that time constraints prevented measurement of DO to the point at which the limiting oxygen concentration was reached.

\section{Results}

The respirometer was used to determine routine metabolic rate (Figure 4) and limiting oxygen concentration (Figure 5) on egg mass samples ranging in age from 0 to $5 \mathrm{~d}$ postfertilization. A total of 10 different spawns were examined, but because of time constraints, only three or four different spawns were measured on any given day.

Metabolism of the channel catfish eggs (embryos), measured as $\mathrm{O}_{2}$ consumption, ranged from $4.8 \pm 1.3$ $\mathrm{mg} \cdot \mathrm{kg}^{-1} \cdot \mathrm{h}^{-1}$ at $1 \mathrm{~d}$ postfertilization to $174.0 \pm 7.8$

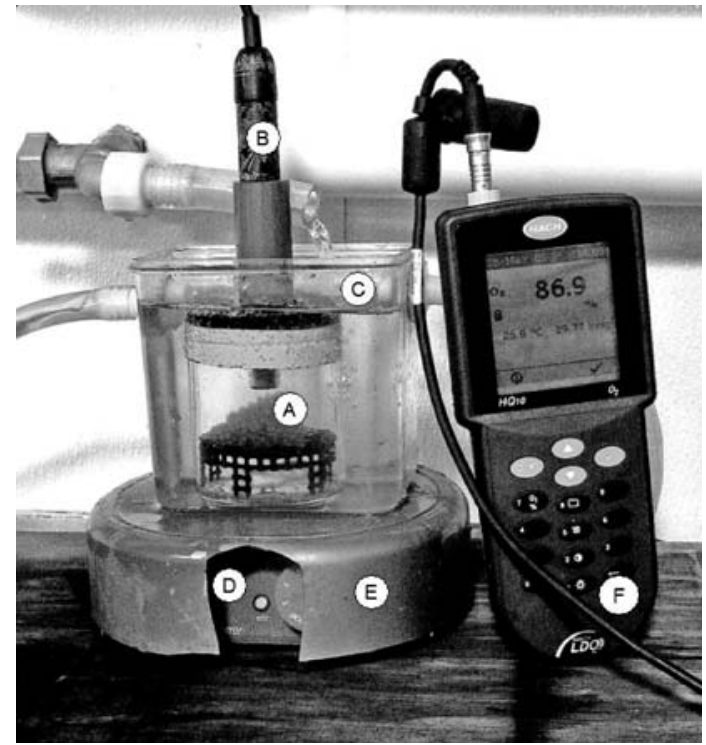

FIGURE 2.- Stirring respirometer in use, showing (A) the channel catfish spawn sample on the screen platform, (B) the oxygen sensor inserted into the respirometer, which was placed in (C) a water bath on (D) a magnetic stir plate, which was protected by (E) a plastic shield. The (F) analyzer could be programmed to automatically sample and record dissolved oxygen concentration and temperature.

$\mathrm{mg} \cdot \mathrm{kg}^{-1} \cdot \mathrm{h}^{-1}$ at $5 \mathrm{~d}$ postfertilization (Figure 4). By $6 \mathrm{~d}$ postfertilization, the eggs in all spawns had hatched. The limiting oxygen concentration increased from $29.3 \%$ saturation at $1 \mathrm{~d}$ postfertilization (one data point only) to $87.1 \pm 2.7 \%$ saturation at $5 \mathrm{~d}$. When eggs were within $1 \mathrm{~d}$ of hatching ( $5 \mathrm{~d}$ postfertilization), I observed that allowing the DO concentration in the respirometer to continue falling below the limiting oxygen concentration resulted in premature hatching. Often, the entire sample would hatch in 1-5 min.

The respirometer proved effective at measuring both the routine metabolic rate and the limiting oxygen concentration. An attempt was made to determine the metabolic rate of channel catfish sac fry, but the respirometer as designed proved unsatisfactory. The heads of the sac fry were small enough to penetrate the mesh of the screen separating the main chamber from the spin bar, and they became entangled. Rather than redesign the respirometer with a finer screen, I used other methods for later studies of sac fry and swim-up fry metabolism.

Although these are preliminary data, they do allow for some hatchery management recommendations. Whereas the mean limiting oxygen concentration for eggs $1 \mathrm{~d}$ prior to hatching ( $5 \mathrm{~d}$ postfertilization) was $87.1 \%$ air saturation, the highest value determined for 


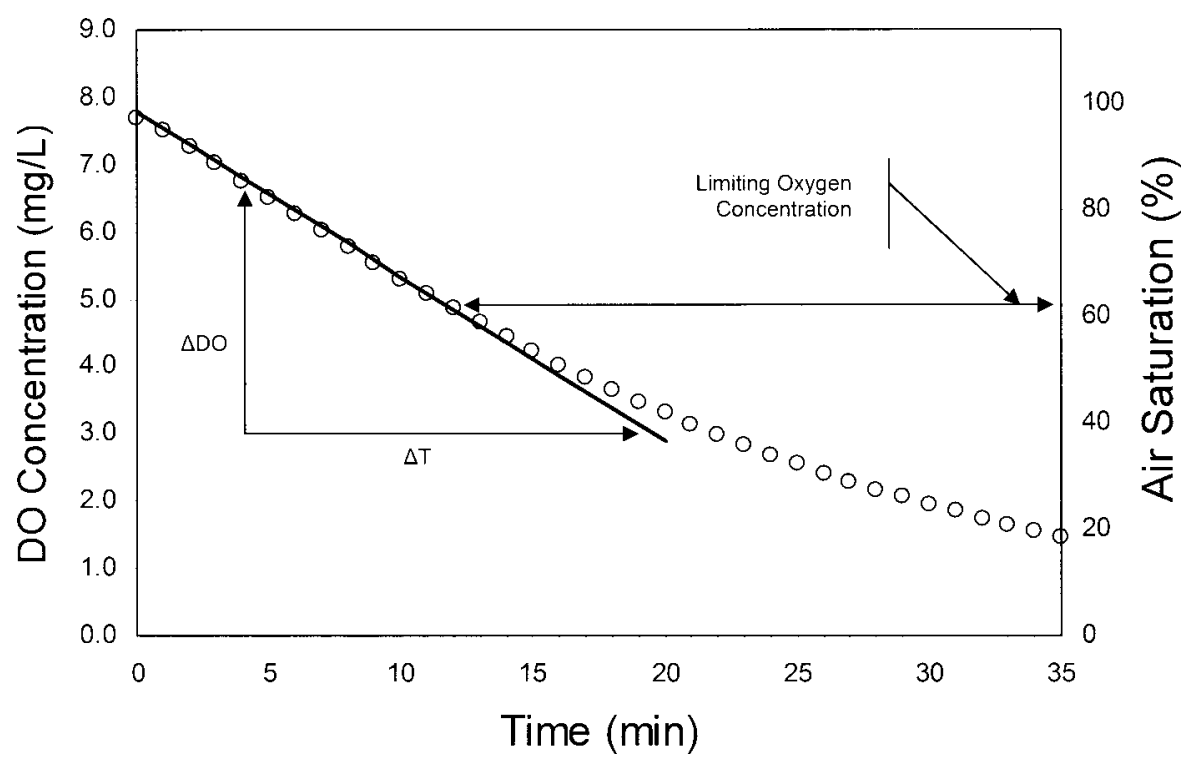

FIGURE 3.-Change in dissolved oxygen (DO) concentration $(\mathrm{mg} / \mathrm{L})$ and air saturation $(\%)$ observed on a representative channel catfish spawn sample. Oxygen consumption rate (change in $\mathrm{DO}$ over time; $\Delta \mathrm{DO} / \Delta \mathrm{T}$ ) obtained from the linear portion of the graph was used with the net water volume and egg sample weight to calculate the routine metabolic rate $\left(\mathrm{mg} \mathrm{O}_{2} \cdot \mathrm{kg}^{-1} \cdot \mathrm{h}^{-1}\right)$. The presumed hypometabolic transition zone, below which metabolism became oxygen-dependent (the limiting oxygen concentration), was visually estimated from the graph.

an individual sample was $95.8 \%$ air saturation. If we assume that limiting the metabolism of developing eggs in a hatchery is not desirable, DO concentrations in the trough should be maintained near air saturation $\left(8.1 \mathrm{mg} / \mathrm{L}\right.$ at $\left.26^{\circ} \mathrm{C}\right)$ as eggs near hatching.

A water flow rate of $7.6-11.4 \mathrm{~L} / \mathrm{min}(2-3 \mathrm{gal} / \mathrm{min})$ is suggested in standard troughs $(378 \mathrm{~L})$ with a capacity of $9.0-11.3 \mathrm{~kg}$ of channel catfish eggs (Steeby and Avery 2005). Without additional aeration in the trough and at the higher flow rate, $11.3 \mathrm{~kg}$ of channel catfish eggs would reduce the DO concentration of air-

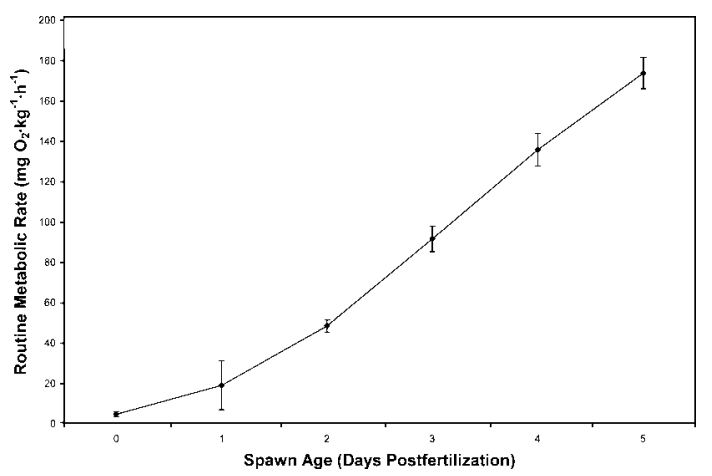

FIGURE 4.- Routine metabolic rate $( \pm \mathrm{SE})$ of channel catfish eggs (a total of 22 measurements on 10 different spawns) ranging in age from 0 to $5 \mathrm{~d}$ postfertilization. saturated inlet water at $26^{\circ} \mathrm{C}$ from 8.1 to $5.2 \mathrm{mg} / \mathrm{L}$ (64.5\% air saturation) —well below the limiting oxygen concentration determined here, and below the concentration shown by Carlson et al. (1974) to negatively impact channel catfish egg pigmentation, growth, and survival to the swim-up stage.

In addition to the recommended water exchange, subsequent aeration of water in the hatching trough is probably necessary to maintain adequate DO concentrations, at least during the last day of incubation, when

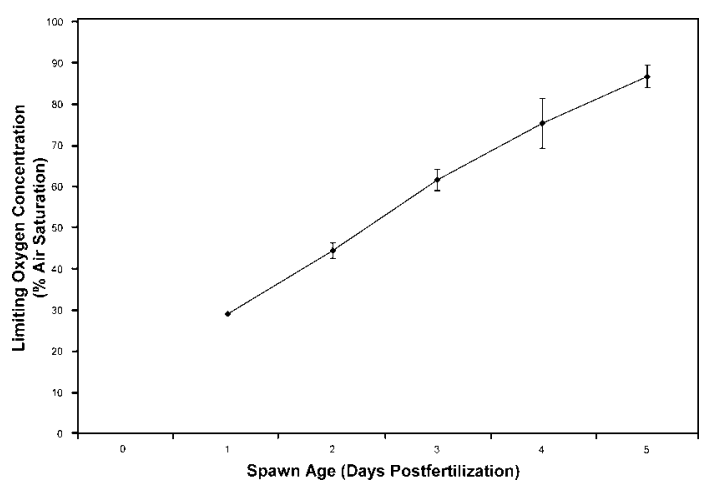

FIGURE 5.- - Limiting oxygen concentration $( \pm \mathrm{SE})$ of channel catfish eggs (a total of 16 measurements on six different spawns) ranging in age from 1 to $5 \mathrm{~d}$ postfertilization. 
metabolism is high and the limiting oxygen concentration is near air saturation. Alternatively, the DO concentration in the water supply could be increased (with liquid oxygen) that is high enough above air saturation to account for respiration in the trough. However, possible negative effects of hyperbaric oxygen on developing channel catfish eggs have not yet been examined.

\section{Acknowledgments}

This research was supported by the USDA-ARS Current Research Information System Number 13320003-00D. Mention of trade names or commercial products in this publication is solely for the purpose of providing specific information and does not imply recommendation or endorsement by the USDA. I would like to thank T. I. Walls, B. Keene, J. B. Jones and T. Bates for their assistance with this study.

\section{References}

Avery, J. L., and J. A. Steeby. 2004. Hatchery management. Pages 145-165 in C. S. Tucker and J. A. Hargreaves, editors. Biology and culture of channel catfish, volume 34. Elsevier, Amsterdam.

Broussard, M. C., and R. R. Stickney. 1981. Reproductive characters for four strains of channel catfish. Transactions of the American Fisheries Society 110:502-506.

Busch, R. L. 1985. Channel catfish culture in ponds. Pages 13-84 in C. S. Tucker, editor. Channel catfish culture, volume 15. Elsevier, New York.

Carlson, A. R., R. R. Siefert, and L. J. Herman. 1974. Effects of lowered dissolved oxygen concentrations on channel catfish (Ictalurus punctatus) embryos and larvae. Transactions of the American Fisheries Society 103:623-626.

Cech, J. J., Jr. 1990. Respirometry. Pages 335-362 in C. B. Schreck and P. B. Moyle, editors. Methods for fish biology. American Fisheries Society, Bethesda, Maryland.

Clapp, A. 1929. Some experiments in rearing channel catfish. Transactions of the American Fisheries Society 59:114117.

Clemens, H. P., and K. E. Sneed. 1957. Spawning behavior of the channel catfish Ictalurus punctatus. U.S. Bureau of Sport Fish and Wildlife, Special Scientific Report, Fisheries 219, Washington, D.C.
Czihak, G., R. Peter, B. Puschendorf, and H. Grunickle. 1979. Some data on the basic metabolism of trout eggs. Journal of Fish Biology 15:185-193.

Jensen, J., R. Dunham, and J. Flynn. 1987. Producing channel catfish fingerlings. Auburn University, Cooperative Extension Service, Circular ANR-327, Auburn, Alabama.

Lee, J. S. 1991. Commercial catfish farming, 3rd edition. Interstate Publishers, Danville, Illinois.

Ringle, J. P., J. G. Nickum, and A. Moore. 1992. Chemical separation of channel catfish egg masses. Progressive Fish-Culturist 54:73-80.

Saksena, V. P., K. Yamamoto, and C. D. Riggs. 1961. Early development of the channel catfish. Progressive FishCulturist 23:156-161.

Small, B. C., and T. D. Bates. 2001. Effect of low-temperature incubation of channel catfish Ictalurus punctatus eggs on development, survival, and growth. Journal of the World Aquaculture Society 32(2):189-194.

Small, B. C., and W. R. Wolters. 2003. Hydrogen peroxide treatment during egg incubation improves channel catfish hatching success. North American Journal of Aquaculture 63:314-317.

Steeby, J., and J. Avery. 2005. Channel catfish broodfish and hatchery management. Southern Regional Aquaculture Center, Publication 1803, Stoneville, Mississippi.

Steeby, J. A., J. Nobile, and W. Wright. 2004. Safer highdensity polyethylene plastic paddles for hatching channel catfish eggs. North American Journal of Aquaculture 66:334-335.

Steeby, J. A., and B. A. Wagner. 2005. Channel catfish hatchery and fry production practices in the U.S. catfish industry. World Aquaculture 36(4):14-17.

Tucker, C. S. 1984. Water quality in channel catfish (Ictalurus punctatus) hatcheries. Mississippi State University, Mississippi Cooperative Extension Service Research Report 8(16), Mississippi State.

Tucker, C. S., and E. H. Robinson. 1990. Channel catfish farming handbook. Van Nostrand Reinhold, New York.

Tucker, C. S., and J. A. Steeby. 1993. A practical calcium hardness criterion for channel catfish hatchery water supplies. Journal of the World Aquaculture Society 24(3):396-401.

USFWS (U.S. Fish and Wildlife Service). 1984. Third report to the fish farmers: the status of warmwater fish farming and progress in fish farming research. U.S. Fish and Wildlife Service, Washington, D.C. 